\title{
Governance in an emerging suburban world
}

\author{
Governança em um mundo suburbano emergente
}

Pierre Hamel

Roger Keil

\begin{abstract}
Cities are increasingly defined through their peripheries. This observation is the result of what has been explored by urban researchers worldwide. Suburban development, with diverse modalities of governance - through the state, capital accumulation and private authoritarianism - is transforming city regions in an unexpected way. The diversity of spatial forms shaping urban/suburban development is part of a peripheral growth bringing in a new scale for understanding urban issues, the metropolis or the city region. The paper is subdivided in four parts. First, we take into account the expansion of suburban spaces in order to highlight the new urban issues emerging at a city regional scale. Second, we look at framing the mechanisms of suburban governance. Then, after paying attention to the Canadian situation, we compare the model of suburban governance in Anglo Saxon settler societies to other forms and/or models of suburbanization prevailing in other parts of the world.
\end{abstract}

Keywords: suburbs; cities; actors; governance; Canadian suburbs; post-suburban realities.

\section{Resumo}

Cada vez mais, as cidades estão sendo definidas através de suas periferias. Essa observação resulta do que tem sido explorado por pesquisadores urbanos no mundo todo. 0 desenvolvimento suburbano, com diversas modalidades de governança - através do Estado, acumulação de capital e autoritarismo privado - está transformando as regiões das cidades de uma forma inesperada. A diversidade de formas espaciais que modelam o desenvolvimento urbano/ suburbano faz parte de um crescimento periférico que está introduzindo uma nova escala para se compreender as questões urbanas, a metrópole ou a região da cidade. 0 artigo está dividido em quatro partes. Primeiro, consideramos a expansão dos espaços suburbanos para ressaltar as novas questões urbanas que estão emergindo em escala regional. Em seguida, nos debruçamos sobre os mecanismos de governança suburbana. Finalmente, após abordamos a situação canadense, comparamos o modelo de governança suburbana em sociedades colonizadoras anglo-saxãs a outras formas e/ou modelos de suburbanização que prevalecem em outras partes do mundo.

Palavras-chave: subúrbios; cidades; atores; governança; subúrbios canadenses; realidades pós-suburbanas. 


\section{Introduction}

Due to recent transformations of metropolitan and/or city regions, suburban spaces have seen their traditional representations as exclusive bedroom communities fade away. This is related to impressive processes of urban-suburban expansion everywhere, but also to restructuring inherent in new forms of suburbanism. From now on, it is no longer possible to look at suburbanization as an incidental or marginal phenomenon. On the contrary, the intensity and diversity of suburbanization has made it the key component characterizing the cities of today and tomorrow. In other words, to better understand the new and changing landscapes of contemporary urban settlements, it is necessary to pay close attention to suburban living as a way of life. But it is also how citizens, political elites and city builders make choices regarding the urban periphery that is at stake. For this reason, understanding suburban living cannot be achieved satisfactorily without considering issues of governance. The fact that landscapes of global suburban expansion and diversifying suburbanisms are challenging the usual reading of the urban in most theories of the city is one of the main starting points to our reflection. This is what we would like to explore in this article. ${ }^{1}$

For that matter we have divided what follows into four parts. First we will consider the relevance of expanding suburban spaces and their governance for understanding the new challenges faced by cities and/or city regions. Second, we will focus on what is required, from a theoretical standpoint, for analysing suburban governance. Third, special attention is given to the Canadian example.
And fourth, before concluding, it is necessary to recall the implementation of different models of suburban governance in different regions of the world.

At the outset, it should be clear that our intention is not to construct a "distinctively suburban theory" (Vaughan et al, 2009: 475). Instead, we want to confront existing elements of urban theories to the materiality of current suburban expansion. This is an unavoidable first step for exploring the significance of ongoing restructuring of the urban globally.

\section{Expanding suburban spaces and their governance}

Suburban spaces exhibit a diversity of spatial forms and social characteristics. Whether we consider the "classical" model of single family home tract housing, the high-rise dominated "modernist" suburbs of Europe or Canada, the squatter settlements of Asia and Africa, the gated communities of California, Brazil or South Africa or the explosive extension in mega-urban India and China, they are all contributing to suburban growth. In addition, the post-suburban environments of existing - even shrinking - metropolitan regions are home to many, if not most of the "urban century's" population. Few of us live "downtown", most live, work and play across the urban region in formerly or currently suburban neighbourhoods, sectors, quartiers. There is no doubt that, from a political economy perspective, the current trends supporting urban growth or the development of cityregions are resulting primarily from peripheral urban growth. What was considered a specific 
post World War II phenomenon, primarily tied to the Keynesian-Fordist production of space, has now become a universal process with "suburban constellations" arising around the globe (Harris 2010; Keil 2013). Such a tendency has not been difficult to observe in Canada where the concentration of population in cityregions over the last decades was particularly strong (Hiller, 2010). But this observation can easily be extended to a global scale. This is at least one of the key hypotheses underlying our thinking. For us, urban growth and urbanization at a global scale are materializing primarily through metropolitanization that can be defined, on the one hand, by the internal social and spatial structuring of metropolises and, on the other, by the building of a system of metropolises at a global scale (Bassand, 2007; see also Brantz et al., 2012). And this is being achieved mainly through peripheral urban growth. Processes of suburbanization are now subsumed within emerging megalopolitan spaces. 'Suburbs' are a 'zombie category' at odds with the contemporary form of urban regions, while outer suburban and exurban spaces continue to rapidly expand and define the growth of 'edgeless cities' (Lang and Knox, 2008). It is possible, therefore, to identify suburbs as one 'moment' of development and life within growing megalopolitan regions.

Suburban growth and expansion is certainly not a new phenomenon. Suburbanization has been part of urbanization and urban development as long as urbanism has emerged as a form of life or as a mode of collective organization (Vieillard-Baron, 2011; Teaford, 2011). In addition, in the field of urban studies and more specifically urban history, suburbs and suburbanization have been researched widely (McManus and Ethington, 2007). Different aspects investigated by researchers have included both the conditions leading to the establishment of suburbs and the forces contributing to their transformation. In that respect, the diversity of factors taken into account in urban studies - including ethnicity, race, economics and social activities - have contributed to our understanding of the complexity and transforming character of these settlements (Nicolaides and Wiese, 2006). That said, these studies predominantly focused on specific cases and historical contexts and paid little attention to the universal and particular forces involved in suburbanization processes and their consequences on the 'suburban ways of life' - which we refer to as suburbanism(s). These are defined jointly by structural factors and subjective cultural choices characterizing different situations that are influenced by national and regional contexts. Because of that omission and given our political-economy perspective, we see a need to pay greater attention to a diversity of geographical settings with a focus on how suburban expansion is transforming city-regions and how suburbanism(s) are part of social transformations (Moos and Mendez 2015).

The multiple urban realities we see when considering suburbs and suburban growth from a global perspective highlight the importance of historical and geographical differences. Although these two entry points do not always converge, they nonetheless contribute complementary information that enhances our understanding of current (sub)urban issues. The suburbs are now an unpredictable landscape, especially compared to the 
traditional representation of the suburban model generally associated with the EuropeanAmerican experience to the divergent forms and processes that characterize peripheral urban development in the Global South where one now sees a proliferation of suburban forms and ways of life, not just a uniform "planet of slums" (Davis 2006; McGee 2015). Equally, the classic picture of American suburbs as middleclass haven is no longer valid. The account by Lisa McGirr (2012) of the climbing rates of poverty in the US suburbs is indicative of the changes that are taking place in that country: "In many of America's once pristine suburbs, harbingers of inner-city blight - overgrown lots, boarded up windows, abandoned residences are the new eyesores" (see also Anacker 2015). Since 2008, U.S. suburbs have been increasingly populated by the poor. This development certainly puts some distance between the current situation and the historic vision of suburban development once traced by Kenneth T. Jackson (1985) in his famous account of "crabgrass frontier".

A careful yet not uncontested consensus is emerging in the field of urban studies: contributing actively and through diversity to metropolitanization, suburban processes are reaching a new qualitative stage. This is what the notion of post-suburbia as coined by Jon C.Teaford (1996; see also Phelps and Wu 2011) is trying to get at. Building on previous conceptual proposals - edge cities (Garreau, 1991), exopolis (Soja, 1989), and outer cities (Herrington, 1984) - Teaford underlines that metropolitan sprawl has fundamentally changed not only the pace and structure of metropolitanization but also its political culture and management, introducing a growing divorce between urban and anti-urban values, including the culture of localism. Other researchers have also devoted attention to the multi-faceted expansion of suburbia and have suggested to describe and name the phenomenon in new terms: outer cities (Herrington, 1984), cities without cities (Zwischenstadt) (Sieverts, 2003), metroburbia (Knox, 2008), boomburbs (Lang and LeFurgy, 2007) to just name a few.

All these contributions point in the same direction. It is not longer possible to ignore the social, cultural, economic, and political transformations produced by suburban expansion and its impact on city-regions. But what are the social consequences of these urban transformations? What forces and actors are responsible for the collective choices involved in suburbanization and metropolitanization processes? With regard to political economy, what are the main driving forces? And finally, what are the resources and opportunities for political regulation? In other words, in what terms has suburban governance been defined and experienced in different regions of the world: in what way have suburbs, suburban elites, or the political class in charge of state initiatives regarding suburbs, suburban expansion and suburbanism, been involved in the governance of suburbs?

For us governance remains a contested notion and primarily an "empty signifier" (Offe 2009). For that matter, governance does not tell us much about what interests shape the power relationships involved in negotiation and decision-making processes. Bringing together representatives of markets or private enterprises, state authority, and citizens, governance promotes cooperation 
between these actors, even though it is always possible that cooperation can being channelled or even manipulated to serve special interests. Beyond the ideological claims of a lessening of class interests under governance discourse, one has to be aware of class response to public challenges in the context of neoliberal austerity (Davies, 2011). Instead of leading to more democracy, governance mechanisms under neoliberal rule have often resulted in more authoritarianism in process and outcome (Swyngedouw, 2005). Institutional changes that have taken place in the political field since the 1980 s are clearly a big concern. The emergence of the governance model in the urban literature has undoubtedly reflected a shift in "how we conceptualize urban governments as governments" (Andrew, Graham and Phillips, 2002, p. 12). Processes of policy-making are taking a new form:

Policy-making no longer separates neatly policy-makers from policy-takers, nor does it distinguish between public and private actors in all type of roles throughout the policy process. The polity structures addressed by political mobilization and that produce policy decisions are not solely those of the nation-state, but those of other polities (...). (Piattoni, 2010, p. 249)

Taking into account the way reflexivity and professional specialization has transformed the political context, the reference to the notion of governance is being used in a critical way. Instead of looking at it as a 'fait accompli', we refer to it as a working tool for exploring how policy-making regarding suburban expansion and suburban way of life have been institutionalized and/or have been underway around the world. But does addressing how suburban governance has been implemented in the Global North and the Global South solve all the theoretical issues suburban governance has to deal with?

According to Dennis R. Judd (2011, p. 17) an "all-encompassing theory" of the city is "impossible to achieve". And we can say the same for urban-regions where suburban expansion is taking place. This does not mean that theoretical concerns are useless. In fact, we think exactly the opposite is true. To gain a better understanding of the way suburban governance is taking shape and is managed in different parts of the world, it is important to raise conceptual concerns and to discuss the implications of theoretical choices involved in defining suburban expansion and suburbanism(s) as specific object of study. The universalization of urbanization has to be taken seriously not only as an empirical object of inquiry but also as a challenging issue at a theoretical level.

\section{Framing the mechanisms of suburban governance}

A large literature explicitly investigates how urban regions are governed. Immigration policies, housing, infrastructure, transportation and development processes contribute to the process of governance. Whether it is urban regime theory, growth coalitions, regulation theory, or accounts of urban social movements, we have many conceptual resources for understanding how urban-regions are planned, built and are struggled over. However, much 
less attention has been paid to the question of suburban governance; specifically the constellation of public and private processes, actors and institutions that determine and shape the planning, design, politics and economics of suburban spaces and everyday behaviour. Admittedly, a range of different scholars and (sub)urban commentators have explored the regulation of suburban spaces and processes of suburbanization (see Young 2015). Yet, often the discussions are not couched in the language of governance per se (for an exception see Phelps et al., 2010; Phelps and Wood, 2011). At the same time, any survey of the existing literature would reveal that it is exceedingly difficult to pin down exactly what suburban governance means and how it is practiced. In fact, suburbs and their social meanings are connected to the history of different national contexts (Faure, 2010). As underlined by John Archer (2005), in England and America, ongoing contentious issues are the results of the Enlightenment project that one can find at the basis of Western values, starting with the material world. Therefore, the array of descriptors across different geographical and linguistic areas makes the task of ascertaining similar and different modes of suburban governance difficult yet still a necessary project (Harris and Vorms forthcoming).

Thus, our aim is to develop a framework, and argument that accounts for the universalization of suburbanization, while maintaining a focus on the particular manifestations of this global process. It is true that different descriptors of suburban life signify particular forms of decentralized urban space. Yet behind all of these forms of suburbs are the processes of urbanization and suburbanization, or what Lefebvre (1968; 2003[1970]) has theorized as an "urban revolution". At the time of writing, Lefebvre's revolution was a provocative hypothesis. The globalization of neoliberal capitalism has furthered the decentralization and universalization of urban space at a global scale and, as Lefebvre postulated, is transforming aspects of everyday life and 'space' of the urban. Powerful processes of uneven development, capital accumulation, migration and agricultural transformations have resulted in varied forms of peri-urban development that touch all urban-regional spaces. However, the universalism of this process should not occlude the particularities of how suburbs are produced and lived. Both the form and content of different suburban spaces are heavily path-dependent, reflecting different political, economic, cultural and environmental histories. Moreover, the social and ecological histories affecting the permutations of suburbanization and forms of everyday life are marked by relations of power, inequality and marginalization, which profoundly affect the trajectories of suburban growth and decline.

Suburbanization has certainly taken the form of a global process (Harris, 2010; Keil, 2011; 2013), yet we lack a comprehensive assessment of the forces of governance that guide the proliferation of peripheral urbanization. The problematic of governance involves accounting for the particular manifestations of the more general urbanregional process of decentralization. The governance of suburbanization and attendant forms of everyday life are a matter of identifying the constitutive dynamics that shape and influence how suburbs are produced 
and experienced. Governance contains a politics of suburbanization that facilitates its process but also questions the effects of growth (and decline). It can be part of a more general politics of scale but can also entail a number of social and economic dynamics in which politics may be present but invisible. The question we ask then is as follows: What are the universal and particular forces shaping suburbanization processes in different urban-regions?

In broad terms there are two central aspects of suburban governance, the first of which concerns how processes of suburbanization and forms of suburbanism are differentiated historically and geographically. Yet at the same time, in an increasingly globalized urban world, suburbanization processes in different spaces are guided by similar practices whether it is, for example, annexation (Cox, 2010; Kennedy, 2007; Zhang $\& W u, 2006)$ or the diffusion of ideologies that sanctify decentralization, public choice and private homeownership (Langley, 2009; Marcuse, 2009). Thus the second aspect of suburban governance entails accounting for the points of convergence regarding how suburbanization proceeds whether in Eastern Europe, the United States, South Asia and in a range of other spaces. Suburban governance entails accounting for both the converging and diverging patterns of peripheral development. Doing so requires paying attention to the varied agents, methods, relations and institutions through which development is managed. Together, these can be viewed as the mechanisms of suburban governance.

One then has to keep in mind that mechanisms of suburban governance are also increasingly taking place at the scale and within the space of city regions (Addie and Keil 2015; Keil et al., 2016). In fact, the problems of political regulation that public authorities are facing are more and more inscribed within metropolitan areas where specific issues (socio-spatial segregation, security, environment, health, education, matters of sustainable development) are being discussed. Metropolises are not only the main location where it is possible to observe the restructuring of relations between state and civil society, but also the main sphere directly affected by social changes related to neoliberalism (Jouve, 2005). Thus, from a political economy perspective, the new territorial frames associated with metropolises are becoming the spaces where a new capitalist regulation is implemented and where capitalist contradictions are transferred to, but also the scale where new compromises have to be worked out (Baraize and Négrier, 2001). An important gap remains, however, between metropolitan institutions on the one hand and functional territories on the other (Lefèvre, 1998; Keil and Addie 2015; Phelps et al. 2010, p. 378). One of the central tensions of governing suburbanization and postsurbubanization is the misalignment between political institutions and the rapid growth of decentralized development, which continually transforms the territoriality of urban-regions (Boudreau et al., 2006; Boudreau et al., 2007; Le Galès, 2003; Phelps and Wood, 2011, Phelps et al, 2010; Young and Keil 2014; Keil et al., 2016).

Three styles of suburban development can be identified: self-built, state-led and private-led suburbanization. These three forms of suburban development do not unfold in a teleological manner from one stage to 
another but rather each type of suburban expansion is evident in different historical moments and spaces. Self-led peri-urban growth is serendipitous and occurs without detailed planning. The scale of development ranges from individual, residential and commercial developments to large tracts of informal housing. This type of development is thus fragmented and heterogeneous and is typified by low regulation. Infrastructure tends to be poorly developed and characterized by the type of disconnectivity that Graham and Marvin (2001) describe as "splintered urbanism". In contrast, state-led suburbanization is centralized, planned and directed by government agencies. This style of suburbanization is dependent on conscious establishment of residential, industrial and commercial developments, often through deliberate zoning and planning processes. Infrastructure connectivity tends to be utilized as a lever for guiding and regulating the development process. Market- and private-led development tends to involve decentralized control yet the state plays a facilitative role in terms of land-use, labour and environmental policy and judicial and legislative frameworks. This type of suburbanization takes commercial, residential and industrial forms although is defined by political and social exclusion. Development is exclusively for profit and tends to be uneven as new spaces boom while others decline. These three different forms of suburbanization represent 'ideal-types' that nonetheless represent concrete forms and processes of suburban development - albeit affected by particularities of history and geography. In contrast to periodizing suburban expansion and decline, distinguishing between self-led, state-led, and market- or private-led development avoids taking the Euro-American case as fundamental and highlights divergent yet comparable processes in different spaces.

In all of its forms, suburban development is led by distinct but complementary modalities of governance through the state, capital accumulation and private authoritarianism. Different state forms have played a role in suburbanization processes. At the same time, it is important not to view the state as monolithic but rather it is crucial to see the scaled nature of states and to consider the state as a site of social conflict crystallized, however momentarily, in an institutional form. Emphasizing the role of capital in the making of suburban life allows us to acknowledge how a range of practices, including industrial relocation and financialization, have defined the suburbanization process and suburbanism itself. The power of capital has been closely bound to that of the state but it is impossible to understand the state without considering capital and vice versa. If relations between state and capital are at the heart of suburbanization and the forms it took in different contexts, the recent financial and political crisis highlight how local economic development is currently challenged by two major problems: firstly, the pressures coming from external flows as the result of economic globalization, secondly, the weakening of the State ${ }^{2}$ as responsible for social and economic redistribution (Mongin, 2008). Tendencies towards privatized authoritarian forms of governance have been very strongly linked with recent suburban development. Gated communities can be considered here as the core of a range of governmentalities in which socio-spatial differentiation has morphed 
into a more coercive landscape of exclusion and segregation.

We are proposing these three modalities here as a conceptual framework for a discussion on governance of suburbanization and increasingly diverse ways of suburban life. We suggest that tensions between these modalities will rise as they often have incompatible processes, goals and outcomes. Most importantly, the dynamics of the various suburbanism ways of life that unfold in the emergent peripheries of our cities rebel against the governmentality (Foucault, 2003) of the suburbanization process that produced and conditioned them.

Often it is assumed that the US experience represents the paradigmatic case of suburbanization that other cases are measured against. Suburban spaces such as Levittown, New York, are often held up as idealized versions of suburbanization. However, one of the key points of agreement in the blossoming literature on suburbs is that diversity is the norm rather than the exception, which means that Levittown is but one form of suburbanization. This is even more evident when we consider the range of suburban development occurring in post-socialist states (Hirt, 2007; Hirt and Petrovic, 2011), China (Feng, Zhou and Wu, 2008; Zhang and Wu, 2006), India (Dupont, 2007; Kennedy, 2007), Africa (Davis, 2006; Grant, 2005) and even within Europe and North America, where we see denser or nonconforming forms of suburbanization (Fishman, 1987; Freund, 2007; Young, 2006). In terms of the governance of suburbanization, Ananya Roy (2009) pushes us to consider multiple worldly forms of governance, not as derivative of the US experience, but rather as central to the increasing suburbanization of urbanregions in all spaces including the US. Much more, suburban forms classically associated with English and American suburbs, such as the bungalow, villa and veranda all have their roots in places such as India and the Mediterranean and were appropriated through colonial processes (King, 2004). In their own ways, both Roy and King illustrate the necessity of going beyond the North American and European suburban experience and push us to consider different worldly forms of suburbanization. In this paper, though, we will start close to home with a sketch of suburban governance in Canada.

\section{The example of Canadian suburbs}

We begin with some historical and definitional perspectives before looking at Canadian suburbs through the complex lens of the country's federalism, its regional diversity and institutional specificity. From an historical perspective, Canadian urbanization is entrenched in the European tradition. At the outset, spatial organization and urban forms were clearly influenced by the model of centrality that has contributed to define the classical European city. However this model was profoundly transformed during the 19th century by the North American liberal culture defined around individuality, freedom and ownership. The priority given to consumer preferences was a direct consequence of that culture and has had a predominant influence in regards to suburbia and its distinctiveness. In this sense, it is very much in line with the other 
cases in this section of the book that highlights the classical Anglo-Saxon cases. It reflects the governmentality of white settler societies in a perceived environment of abundance and spatial limitlessness, opportunity to break class and ethnic restraints, and individuality.

Urban Canada is made up of regions (Central Canada, Atlantic Provinces, Western Provinces and Northern Territories). Historical, geographical and cultural differences have contributed to support suburbanization processes considered as major components of metropolitanization. Here we have to recall that "as early as 1825, Canada was one of the most urbanized countries in the world" (Hiller, 2010a, p. XV). This is due to the choice of concentration in viable settlements made by the colonizers and the population. Since then, this trend has been constantly reinforced. According to the 2006 census, the Canadian population was strongly concentrated within the six major metropolitan areas: "(...) nearly half of the Canadian population (45 per cent) reside within them" (Hiller, 2010a, p. XVIII).

To grasp this reality and the fact that urban growth is taking place in all census metropolitan areas (CMA), including the choice of urban and suburban forms as decided by economic, social and political actors, it is necessary to better understand the specificity of Canadian municipalities, both urban and suburban. The federalist context as it was defined in 1867 by the constitution and evolved as a result of a cultural, economic and political compromise and through a fundamental conflict between centralizing and decentralizing forces - has played a major role. In Canada, municipalities do not have an autonomous status as they have, for example, in US federalism. Their autonomy is directly circumscribed by provincial legislation and authority.

Taking into account regional differences and the presence of two distinct cultures at the root of the Canadian political compromise, a separation of powers has been established between the provincial and federal levels. As stipulated in the British North America Act (BNAA) of 1867, local issues and responsibilities are exclusively a provincial matter. Thus, provinces are responsible for ensuring that local land management and planning meet the needs of Canadians. However, despite the establishment of a clear separation of powers between the provincial and federal levels, grey areas of litigation did not take long to occur between the two tiers. We lack the space here to revisit the history of these conflicts, but one must emphasize that the spending power and specific prerogatives of the federal government allowed Ottawa to influence the development of municipalities and urban areas. The federal government has not hesitated to take the initiative and support the financing of households for home ownership towards the creation of the Canadian Mortgage and Housing Corporation (CMHC) or the construction of transport infrastructures. We will look at these central avenues for suburban governance in detail below.

Today Canadian suburbs are changing rapidly. The rather stereotypical view that saw the suburbs as categorically different from the inner city has been widely challenged. Canadian suburbanization has traditionally been influenced by the American and the European models. While in Canada, as in the UK, the US and Australia, "the suburban ideal 
was ... luring residents to a detached house along the metropolitan fringe" (Teaford, 2011, p. 23), even the single-family home suburbs like Toronto's Don Mills "included many townhouses and apartments" (Teaford, 2011, p. 27). Working class suburbanization has been another distinctive feature of suburbanization in Canada historically (Harris, 1996; Fiedler and Addie, 2008, p. 6). Although more recently eclipsed by the "creeping conformity" (Harris, 2004) of mass-produced middle class suburbanization, the self-built proletarian suburbs in Toronto were prototypical and changed the way suburbanization has been viewed in Canada.

Notably, the state has had a visible role in structuring the suburban landscape and in ordering the space of the periphery (Keil and Young, 2011). As a result of the specific interaction of state, market and authoritarian governance (public and private) in Canada, we find both the single-family home subdivisions typical for the US and the highrisedominated peripheral ensembles associated with suburbanization in Europe. Uniquely, though, suburban Canada has now become a remarkable new model of development that is largely defined by the immigrant experience and the diversity of new suburban populations. While Australian and American suburbs have also become havens of new immigration and increasing demographic diversification (including a tendency to see rising poverty levels in urban peripheries), the Canadian case seems to be most advanced in showing cracks in the classic Anglo-Saxon model of white middle class suburbanization. Three things have changed in recent years in Canada:
Suburbanization has become more diverse in every respect. For example, ethnic diversity in Toronto's periphery is now unmatched anywhere. The white middle class suburbs of the post-war years are largely gone. The 'old' or 'inner' suburbs have huge and very diverse non-white and immigrant populations (Hulchanski, 2010). Terms like the 'racialization of poverty' and 'vertical poverty' are now strongly associated with the extensive suburban tower neighbourhoods where the combination of immigration, renter status and visible minority membership as well as gender has become a predictor of structural poverty (United Way of Toronto, 2011). More significant perhaps are the concentrations of immigrant populations in some newer suband exurbs such as Brampton, Mississauga and Markham. The phenomenon of the diverse suburb needs to be understood in relation to the continued formation of the global city region and the emergence of postcolonial and postmetropolitan forms of urbanization (Keil, 2011a,b).

The neoliberalization and 'splintering' (Graham and Marvin, 2001) of suburban development has led to a reorientation of metropolitan politics, and a redefinition of political imaginaries and institutional as well as geographic boundaries. It is impossible now to imagine the suburbs neatly sequestered spatially and socially from a categorically different 'inner city'. In fact, most suburban development now takes place in a newly defined in-between city that neither resembles the old inner city and the glamorous cookiecutter suburbs. Clearly, both these spaces still exist both in their gentrified and sometimes gated reality and they attract much attention 
and investment particularly in an era that defines urban development as creative, young and driven by the knowledge economy. Yet, many Canadians now live, work and play in quite undefined and nondescript middle landscapes where everything seems to happen at once: large scale infrastructure like highways and airports are next to residential quarters; all manner of service infrastructures including universities and high tech corridors are adjacent to low rent apartments; parks and parking are side by side; high speed highways and transit deserts define the same space; religious mega-structures are across the street from ethnic mini-malls (Young et al., 2011).

The political equation of regionalization and redistribution has been severed as aggressive suburban regimes have come to power regionally or even federally in Canada to use their political base to fundamentally shift the meaning of metropolitan politics. At the same time, suburban regimes in communities around Toronto (as well as in Montreal and Vancouver) are developing a decidedly autonomous set of strategies to make their mark in an increasingly competitive global city environment. At first glance, this suburban resurgence in metropolitan politics seems to represent a throw-back to earlier periods of regional regulation but closer inspection reveals a new set of political circumstances that have to do with the maturing of a largely suburbanized Canadian urban region and new modes of multilevel governance. As suburban local administrations ostensibly gain more autonomy and influence at a metropolitan scale, some of them have become hotbeds of political and fiscal impropriety. This was expressed recently through conflicts of interests, graft and corruption in peripheral localities as Laval (Quebec), Mississauga and Vaughan (Ontario) as well as Surrey (British Columbia). The causes are numerous, but the relatively limited media coverage of suburban politics may account for the apparent lack of accountability of some political leaders in suburban localities.

Canadian suburbs have been shaped by a multiplicity of factors. The absence of state regulation, the role of federal and provincial governments in supporting access to direct and indirect homeownership, the availability of inexpensive land for suburban expansion and the irrepressible desire of workers for access to homeownership were all elements supporting suburban expansion and its diversified landscape. After the Second World War, with a new wave of suburbanization, suburban municipalities had to contribute to metropolitan governance. As urban issues were increasingly defined at a metropolitan scale, suburbs were involved in decisions regarding transportation, housing and economic development concerning whole cityregions. Thus, the representation of conformity used to define suburbia is necessarily outdated. Within the new context of suburban governance, the priority given to economic and financial concerns raises new challenges for public authorities.

What is distinctive about Canadian suburban governance may be its regional character and its increasing difference from both the European and American models from where it developed its character in the past. Canada is now strongly urbanized and the country's population is concentrated in large metropolitan areas: Toronto, Montreal, 
Vancouver, Ottawa-Gatineau and the CalgaryEdmonton corridor (Bourne et al., 2011, p. 7). In addition, more than half of the population of Canada resides in the Windsor-Quebec City corridor "and seven out of 10 manufacturing jobs in the country are located there [...]" (Hiller, 2010b, p. 28). The importance of this population concentration and the rising power of metropolitan regions throughout the country are certainly important features of the new urban landscape of Canada. There is now a truly Canadian story developing from coast to coast which is internally differentiated (in a federalist context) and shows some remarkable similarities across the nation's (sub) urban reach. Cities, regions and their suburbs are now recognized as central to the governance of the vast territory of Canada, which is beginning to understand itself as a primarily urban country.

The current push in Canada for regional forms of regulation can be understood as a form of state rescaling (Boudreau et al., 2006, 2007; Keil et al., 2016). In the context of neoliberalization and globalization of Canadian territorial government, local and regional modes of governance are assuming new responsibilities. This has to do with interurban and interregional competition for investment and labour (Florida, 2002), with infrastructure provision (Young et al., 2011) as well as with the need to establish an institutional framework to deal with post-welfare state issues of social, economic, cultural and environmental regulation. While the debate on rescaling looks at broader dimensions of social institutions in a changing global geography (Keil and Mahon, 2009), the literature on multi-level governance (Piattoni, 2010) has specifically dealt with the ways in which government distributes responsibilities in federal states.

Suburbanization plays a major part in the rescaling and shifting of responsibilities across a multi-level governance structure. The push into new, often sprawling, suburban peripheries, even in slow growth cities like Winnipeg, is linked to the expansion of the so-called "new economy," and the suburban way of life has become the standard for the new metropolitan normal with consequences for the overall course of policy in an environment of continued devolution, austerity and state restraint. In this context, it is ever more questionable whether Canadian municipalities and regional institutions have the capacity to deal with challenges of immigration, poverty, exclusion and environmental issues wrapped up in the continued push for suburban expansion.

\section{Elements of comparison}

This article talks about suburban governance both as a conceptual terrain and as an object of empirical study. What lessons can we learn from the geographic spread of suburbs?

Through Hamel and Keil (2015), we set up governance in two important ways: In the first instance, it asked how suburbs are planned and designed, conceived and materialized through self-built, state-led and private-led development. But it further proposed to understand governance through three intertwined modalities involving the state, capital and emergent forms of authoritarian governance. In a second move, we put forward to extend governance to processes of suburban life (suburbanisms) 
and post-suburbanization which go beyond the actual original making of the suburbs (suburbanization) and extend towards the governmentalities of (sub)urban life in the 21 st century overall.

In many ways, the term and the phenomenon of suburbanization - and its derivative terms suburbanism, suburb - have been associated most directly with a history of decentralized urbanization that springs in idealtypical form from the combination of liberal capitalist democracy and centrality of property rights. With an original impetus from the British experience - which has been discussed in relation to its Western European neighbors (see Phelps and Vento, 2015) -, suburbanization as it is commonly understood has had its clearest manifestation in the formerly British colonies and settler societies in the United States, Canada and Australia. Two assumptions can be made. First, in these countries, the dream of the detached house at the suburban fringe was not just a figment of the imagination (as it appeared to be in many societies around the globe throughout the 20th century, even those that housed their population mostly in apartments) but it was a built reality as large percentages, in some regions and time periods even the majority of housing units constructed, were single family homes on previously undeveloped land in the outskirts of towns and cities. The centrality of the notion of property ownership coincided with institutional and cultural conditions under which the suburban way of life could thrive in a particular built environment. With it came political form (fragmentation), economic structure (a virtuous cycle of mass production and consumption triggered by Fordist economies of scale), financial institutions (a mortgage system geared towards single family home ownership) usually underwritten by central governments and administered by lower level governments, a cultural disposition towards living on and near the land (arcadian and homesteading ideals co-generative of settler societies more generally), and an optimistic belief in the limitlessness of resources (energy, water, land). The second assumption was that the Anglo-Saxon ideal case is most prototypically expressed in the United States which has been examined by Nijman and Clery (2015) as well as Peck (2015). In the US, more than anywhere else, a stereotypical image of suburban form and life was developed during the 20th century in such a way that, even today, the term suburb itself evokes images of 1950s and 1960s sitcoms (or their nostalgic remakes in the form of the successful current TV series MadMen). While the project on Global Suburbanisms ${ }^{3}$ overall attempts to debunk the American predominance of the notions of suburbanization, suburbanisms and suburban, the American case is a good and necessary place to start not just because the majority of the extant literatures on the matter refer mostly and often exclusively to the American case. The study of Canada (Keil et al., 2016) and Australia (Johnson, 2015) provide important declinations on the Anglo-Saxon experience and perhaps corrections to the stereotype from which other more meaningful links to different competing experiences of suburbanization today can be made.

Having considered the ideal case of suburban governance in Anglo Saxon settler societies, it is necessary to consider existing alternatives as we find in other countries, 
either in Eastern and Western Europe or in Latin America. Some of those cases worldwide have demonstrated significant variation from the time of the onset of industrial era (sub) urbanization. Those cases have been in more or less direct "conversation" with the Anglo Saxon cases through urbanist theory and praxis. The English greenbelt and garden city ideas, for example, had an influence beyond their original town planning context in the UK. The epochal significance of the Charter of Athens that prescribed functional separation since the 1930s as well as the modern planning ideals that followed were both universal in intent and specific in form of built environment and governance. The largely statedriven highrise suburbanization in Western European (and Canadian) welfare states has had similarities in intent, process and outcome with the peripheral housing estates in Eastern Europe after the Second World War. Phelps and Vento (2015) and Hirt and Kovachev (2015) respectively explored both common ground and divergent developments in Western and Eastern Europe during the past few decades. What was perhaps different in particular, and subject of examination, is the notion of shrinkage that has now become a dominant feature of (sub) urban governance in peripheries of Eastern European cities (Kabisch and Rink, 2015). But it has not just been in Europe that we have seen original and alternative suburban development with longstanding histories. The Latin American situation as it has been scrutinized by Heinrichs and Nuissl (2015) provides insight into an interesting and distinctive tradition of suburbanism which, perhaps in absence of the welfare statist version of Europe, has lately been heavy on authoritarian privatism as the main modality of suburban governance.

Emerging models of suburbanization in Africa (Bloch, 2015), in India (Gururani and Kose, 2015) and in China (Wu and Chen, 2015) are not to be understood as versions of Anglo Saxon 'normativity' but as endogenous and autonomous forms of peripheral urbanization that have now come to be the most dynamic and quantitatively most recognizable forms of producing urban settlements worldwide. While these developments are called "emerging" here, they are not exactly new, having been preceded by thousands of years of urbanization in one form or another. They are "emergent", though, in the sense that their new forms of urbanization, which we have noted as largely suburban, are appearing at an unprecedented rate. What is emergent here is not just a mere addition to existing - classical or alternative - forms of suburbanization and governance but an entirely new mode of urbanization altogether, one that defies simple categorization, typology and especially subordination to existing western models of understanding. Modalities of suburban governance in Africa, China and India, therefore, point to emerging forms of life on this planet in a thoroughly urbanized society where most life we call 'urban' exists in the sprawling, low and high density, formal and informal, self-built, state-driven or privately constructed, suburban expanses that cities in those regions consist of.

So what can we take from this global tour d'horizon? Returning to our proposition of three competing and colluding modalities of suburban governance, we can conclude that all three, to varying degree, are present in the different cases we referred to. The state has 
classically enabled and limited certain types of developments in suburban environments through economic incentives, direct intervention (e.g. planning or infrastructure provision), policing and services. Governments at all scales remain particularly present as actors in those places where the state has been known traditionally to shape the urban reality: in Western Europe, in Canada in particular. The most pervasive form of suburbanization through state-led governance is certainly present in China where local state entrepreneurialism plays an increasing role in the development of suburban land. State activity, however, is coupled with one of the fiercest forms of capital accumulation and productive of some of the most authoritarian forms of privatism ever seen on this planet. The traditional Anglo-Saxon cases, the United States, Great Britain, Australia and Canada to a degree, continue on a trajectory, which sees suburban governance mostly aligned with waxing and waning powers of the market. Even after the meltdown of 2008, the accumulation through the production of suburban space continues (almost) unabated. When we say "almost" we refer specifically to the increased formal adaptation through New Urbanist and sustainability-inflected versions of suburbanism that have replaced some of the more vulgar and wasteful forms of sprawl of the past two decades and preach instead the gospel of compact and dense structures and forms. The Anglo-Saxon, market-driven models of suburban governance are now joined world wide by aggressive suburbanization machines in India, China, Africa, Latin America and Eastern Europe, where massive accumulation strategies are based on the sprawling roll-out of the 'American' model as universal form of development. In Western Europe, countries such as Greece, Ireland, Portugal and Spain continue to work through the lingering pain that that strategy inflicted on their economies through speculative overbuilding in their cities' peripheries in the 1990s and early 2000s.

What are the emerging processes of suburban governance? There is a continued tension between the urge for regional governance (see also Keil et al., 2016) and the pervasive tendency for suburban polities to assert themselves separately from the core city but also in contradistinction from each other and in respect to regional government institutions. Fragmentation, political idiosyncrasy and institutional individualism reign supreme in many of the new suburban territories in the world's "cities in waiting". In many parts of the world, suburbanization and post-suburbanization processes present a mixture of formal and informal, institutionalized and spontaneous, state, market and private forms of governance. New political interests are being shaped by political economies of land that are newly invented and articulated with arcane land use practices, along with novel (if often mannerist and derivative) built forms, gross social, spatial and service inequities and new in-between proximities whose political potential are just beginning to unfold.

What are the emerging themes of suburban governance? Shelter and jobs are important, especially in developing nations where suburbanization is still produced by majority rural-to-urban migration. Mobility infrastructures, primary and secondary schooling, taxes remain high on the agendas of suburban politics. The environment, economic 
(especially commercial) development, and community safety are always big issues. The experiences of suburban shrinkage and poverty, post-suburban in-betweenness, and increasing diversity have now become major subjects of suburban governance. Informality in suburban development - be it in squatter settlements or corporate edge cities and research parks continues to be part and parcel of all regional trajectories and necessitates more inclusive forms of suburban governance. In many parts of the world, though, informality continues to be met with strong interventionist measures by the local state to create order on an urban fringe that is seen as out of control. From this divide stem new demands reminiscent of the traditional register of struggles for the Right to the City or "participation, empowerment, and accountability" in the words of Gururani and Kose (2015). It is also the main site for the formulation of a new meaning of a postcolonial suburban politics which redefines political society, as Roy phrased it. We then arrive, as she says at the "suburban periphery [as] a vital site of the remaking of property, power, and the public interest" (Roy, 2015).

Are there new actors in suburban governance? Suburban governance everywhere is firmly linked to the development and sustainability of financing institutions, be this through savings and loan institutions, regular bank credit, mortgages. In Africa, India and China, as well as in the countries of Eastern Europe, mortgage markets had to be developed in order to carry the task of financializing land and financing construction. Institutional innovation and individual entrepreneurship are part and parcel of this fundamentally capitalist set of practices that are now pervasive in suburbanization processes around the world. Furthermore, in the past, we could surmise that suburban governance was firmly entrenched in the logics of the political economy of urban growth. Growth coalitions, growth machines, urban regimes, while often focused on mostly with regards to central municipalities in the Global North, also regulated and facilitated suburban governance beyond the conventional city limits elsewhere. Lately, this terrain has been extended to include the in-between areas of urban regions (Young and Keil, 2014; Dear and Dahman, 2011). The consequences are profound. New actor constellations arise from the booming "ethnoburbs" and "arrival cities" in the outskirts of cities world wide (Saunders, 2010).

Depending on the circumstances, the effects of state-led suburban governance could lead to more spatial justice (Soja, 2010) (as it ostensibly did in Toronto during the formative years of the Municipality of Metropolitan Toronto) or to gross inequalities (as happened in the racialized and classed situation in many US cities or as it turned out to be the case in the recent past in Toronto) (Hulchanski, 2010). The accumulation of capital continues to act as a second modality of suburban governance. Property capital in collaboration with growthoriented municipal governments goes on to push residential frontiers of urban areas outward in an aggressive manner (Logan and Molotch, 1987). Global firms usually get their way in locating their headquarters, back offices and branch plants close to the suburban infrastructures that are ostensibly, yet deceptively, sold to (or rather paid for by) local voters and taxpayers as serving their interests primarily. Universities, colleges and 
school boards play a major role in structuring suburban spaces and investments in their infrastructures (Addie, Keil and Olds, 2014). The roles of capital and of the state are intertwined. Private development capital and developers have played a significant role in suburban growth as well as suburban governance. The third modality of suburban governance is authoritarian and private. Far from naturally increasing the likelihood of democratization (in contrast to government), current forms of governance are often built on through authoritarian, if not coercive technologies of power.

We can view the three modalities of suburban governance as somewhat compatible arenas in which various instruments and technologies of suburban governmentality are being produced. Remarkably, the state has mostly acted in symbiosis with the property industry in pushing suburbanization as a selfpropelling outcome of governance which, in turn, produces expectations about different models of suburban life. Lately, suburbia has occasionally shed its image of an open and liberated domain close to nature and has assumed the look and feel of a camp: enclosed and sequestered, fenced and secured.

\section{Conclusion}

The "urban century", as ours has been labeled, is really defined by an expansion of metropolitan peripheries (Keil, 2013). In large parts of the world, this continues to mean primary urbanization of rural populations on the outskirts of major centres. Indisputably, China (where the government has plans to create settlements for at least another quarter billion peasants in suburban megacities), India and Africa, lead the way with an unprecedented wave of primary rural-tourban migration which will transform not just these countries and continents forever but will shift the balance of populations, economies and powers further from the North and West to the South and East of the planet. Yet in an equally breathtaking simultaneity, those first-time urbanites will be neighbours to established, yet rapidly changing post-suburban landscapes that are revolutionized under the dictates of a neoliberalized, globalized, flexible regime of accumulation. While the cities of the global South still expand at the margins and require provision of first and fundamental collective consumption services, infrastructure and institutional innovation, they already folding in on themselves and demanding immediate attention as urban quarters, internationalized business districts and mature neighbourhoods. The solid difference between original suburbanization and postsuburban realities as explored in this article melts into air. Governance of these spaces remains one of the leading task of the $21 \mathrm{st}$ century. 


\section{Pierre Hamel}

Université de Montréal, Department of Sociology. Montreal, Quebec, Canadá. pierre.hamel@umontreal.ca

\section{Roger Keil}

City Institute, York University, Faculty of Environmental Studies. Toronto, Canadá rkeil@yorku.ca

\section{Notes}

(1) For this, we rely heavily on what has been explored in our edited book (Hamel and Keil, 2015). More specifically what is presented in this article comes mainly from both the introduction and conclusion of the book in addition to chapter 1 (Ekers, Hamel and Keil, 2015) and chapter 4 (Keil, Hamel, Chou and Williams, 2015).

(2) Economic globalization is not a recent phenomenon. But the form it takes since the 1970s in relation to the Fordist crisis is different than what it has been in the past, particularly regarding State restructuring and fiscal tightening. Consequently, State regulation - particularly in reference to suburban governance - goes with deregulation and a revision of past socipolitical compromises (see Bauman and Bordoni, 2014).

(3) Here we refer to the Major Collaborative Research Initiative Global Suburbanisms: Governance, Land and Infrastructure in the 21st Century sponsored by the Social Sciences and Humanities Research Council of Canada (2010-17); see www.yorku.ca/suburbs.

\section{References}

ADDIE, J-P. D. and KEIL, R. (2015). Real Existing Regionalism: The Region between Talk, Territory and Technology. International Journal of Urban and Regional Research, v. 39, n. 2, pp. 407-417.

ADDIE, J-P. D., KEIL, R. and OLDS, K. (2014). Beyond town and gown: universities, territoriality and the mobilization of new urban structures in Canada. Territory, Politics, Governance, v. 3, n. 1, pp. 27-50.

ANACKER, K. B. (ed.). (2015). The new american suburb: poverty, race, and the economic crisis. Farnham, Ashgate.

ANDREW, C.; GRAHAM, K. A. and PHILLIPS, S. D. (eds.). (2002). Urban affairs back on the policy agenda. Montreal \& Kingston, Mc-Gill-Queen's University Press.

ARCHER, J. (2005). Achitecture and Suburbia. From English Villa to American Dream House, 1690-2000. Minneapolis, University of Minnesota Press. 
BARAIZE, F. and NEGRIER, E. (2001). L'invention politique de l'agglomération. Paris, L'Harmattan.

BASSAND, M. (2007). “Métropoles et métropolisation”. In: BASSAND, M. K. V. \& JOYE, D. (eds.). Enjeux de la sociologie urbaine. Lausanne, Presses Polytechniques Universitaires Romandes.

BAUMAN, Z. and BORDONI, C. (2014). State of Crisis. Cambridge, Polity Press.

BLOCH, R. (2015). “Africa's New Suburbs”. In: KEIL, R. \& HAMEL, P. (eds.). Suburban governance a global view. Toronto, University of Toronto Press.

BOUDREAU, J.-A.; HAMEL, P.; JOUVE, B. and KEIL, R. (2006). Comparing metropolitan governance: the cases of Montréal and Toronto. Progress in Planning, v. 66, n. 1, pp. 7-59.

(2007). New State Spaces in Canada: Metropolitanisation in Montreal and Toronto Compared. Urban Geography, v. 28, n. 1, pp. 30-53.

BOURNE, L.S.; HUTTON, T.; SHEARMUR, R. G. and SIMMONS, J. (2011). "Introduction and overview: Growth and change in Canadian cities". In: BOURNE, L. S.; HUTTON, T.; SHEARMUR, R. G. \& SIMMONS, J. (eds.). Canadian urban regions: trajectories of growth and change. Oxford, Oxford University Press.

BRANTZ, D.; DISKO, S. and WAGNER-KYORA, G. (eds.) (2012). Thick Space: approaches to metropolitanism. Bielefeld, Transcript.

COX, K. (2010). The problem of metropolitan governance and the politics of scale. Regional Studies, v. 44, n. 2, pp. 215-227.

DAVIES, J. S. (2011). Challenging governance theory. Bristol, The Policy Press.

DAVIS, M. (2006). Planet of slums. New York, Verso.

DEAR, M. and DAHMANN, N. (2011). "Urban politics and the Los Angeles School of Urbanism". In: JUDD, D. R. and SIMPSON, D. (eds.). The city revisited: Urban theory from Chicago, Los Angeles, New York. Minneapolis, University of Minnesota Press.

DUPONT, V. (2007). Conflicting stakes and governance in the peripheries of large Indian metropolises An introduction. Cities, v. 24, n. 2, pp. 89-94.

FAURE, A. (2010). “Banlieue (pl. banlieues)”. In: TOPALOV, C. et al. (eds). L'aventure des mots de la ville. À travers les temps, les langues, les sociétés. Paris, Robert Laffont.

FENG, J.; ZHOU, Y. and WU, F. (2008). New trends of suburbanization in Beijing since 1990: from government-led to market-oriented. Regional Studies, v. 42, n. 1, pp. 83-99.

FIEDLER, R. and ADDIE, J.-P. D. (2008). Canadian cities on the edge: Reassessing the Canadian suburb. The City Institute at York University (CITY), Occasional Paper, accessed January 30, 2009. Available at: http://www.yorku.ca/city/Publications/OccasionalPapers/index.html.

FISHMAN, R. (1987). Bourgeois utopias: the rise and fall of suburbia. New York, Basic Books.

FLORIDA, R. (2002). The rise of the creative class. New York, Basic Books.

FOUCAULT, M. (2003). Society must be defended. Lectures at the Collège de France (1975-1976). New York, Picador.

FREUND, D. M. P. (2007). Colored property: state policy and white racial politics in suburban America. Chicago, University of Chicago Press.

GARREAU, J. (1991). Edge city: Life on the new frontier. New York, Doubleday. 
GRAHAM, S. and MARVIN, S. (2001). Splintering urbanism. London, Routledge.

GRANT, R. (2005). The emergence of gated communities in a West African context: Evidence from Greater Accra, Ghana. Urban Geography, v. 26, n. 8, pp. 661-683.

GURURANI, S. and KOSE, B. (2015). "Shifting Terrain: Questions of Governance in India's Cities and Their Peripheries". In: KEIL, R. and HAMEL, P. (eds.). Suburban governance a global view. Toronto, University of Toronto Press.

HARRIS, R. (1996). Unplanned suburbs: Toronto's American tragedy, 1900 to 1950. Baltimore, John Hopkins University Press.

(2004). Creeping conformity: How Canada became suburban, 1900-1960. Toronto, University of Toronto Press.

(2010). Meaningful types in a world of suburbs. Suburbanization in Global Society. Research in Urban Sociology, n. 10, pp. 15-47.

HARRIS, R. and VORMS, C. (eds). (Forthcoming). What's in a Name? Talking about 'Suburbs'. Toronto, University of Toronto Press.

HEINRICH, D. and NUISSL, H. (2015). "Suburbanization in Latin America: Towards New Authoritarian Modes of Governance at the Urban Margin". In: KEIL, R. and HAMEL, P. (eds.). Suburban Governance A Global View. Toronto, University of Toronto Press.

HERRINGTON, J. (1984). The outer city. London, Harper and Row.

HILLER, H. H. (2010a). "Introduction: urbanization and the city". In: HILLER, H. H. (ed.). Urban Canada, 2nd Ed., pp. 19-39. Don Mills, Oxford University Press.

(2010b). "The dynamics of Canadian urbanization”. In: HILLER, H. H. (ed.). Urban Canada, 2nd Ed., pp. xii-xxii. Don Mills, Oxford University Press.

HIRT, S. (2007). Suburbanizing Sofia: characteristics of post-socialist peri-urban change. Urban Geography, v. 28, n. 8, pp. 755-780.

HIRT, S. and KOVACHEV, A. (2015). "Suburbia in Three Acts: The East European Story". In: KEIL, R. and HAMEL, P. (eds.). Suburban Governance A Global View. Toronto, University of Toronto Press.

HIRT, S. and PETROVIC, M. (2011). The Belgrade wall: The Proliferation of gated housing in the Serbian capital after socialism. International Journal of Urban and Regional Research, v. 35, n. 4, pp. 753-757.

HULCHANSKI, D. (2010). The three cities within Toronto. Income polarization among Toronto's neighbourhoods, 1970-2005. Toronto, University of Toronto.

JACKSON, K. (1985). Crabgrass frontier: the suburbanization of the United States. New York, Oxford University Press.

JOHNSON, L. C. (2015). “Governing Suburban Australia”. In: KEIL, R. \& HAMEL, P. (eds.). Suburban Governance A Global View. Toronto, University of Toronto Press.

JOUVE, B. (2005). La démocratie en métropoles: gouvernance, participation et citoyenneté. Revue française de science politique, v. 55, n. 2, pp. 317-337.

JUDD, D. R. (2011). "Theorizing the city". In: JUDD, D. R. and SIMPSON, D. (eds.). The City Revisited. Minneapolis, University of Minnesota Press. 
KABISCH, S. and RINK, D. (2015). “Governing shrinkage of large housing estate at the fringe”. In: KEIL, R. and HAMEL, P. (eds.). Suburban Governance A Global View. Toronto, University of Toronto Press.

KEIL, R. (2011a). "Suburbanization and global cities". In: DERUDDER, B.; HOYLER, M.; TAYLOR, P. J. and WITLOX, F. (eds.). International handbook of globalization and world cities. London, Edward Elgar.

(2011b). Global Suburbanization: The Challenge of Researching Cities in the 21st Century. Public, n. 43, pp. 54-61.

(ed.). (2013). Suburban constellations: governance, land and infrastructure in the 21st century. Berlin, Jovis Verlag.

KEIL, R. and ADDIE, J-P. D. (Forthcoming). "Internalized Globalization and Regional Governance in the Toronto Region". In: KEIL, R.; HAMEL, P.; BOUDREAU, J.-A. and KIPFER, S. (eds.). (forthcoming). Governing Cities Through Regions: Canadian and European Perspectives. Waterloo, Wilfrid Laurier University Press.

KEIL, R. and MAHON, R. (eds.). (2009). Leviathan undone? Towards a political economy of scale. Vancouver, UBC Press.

KEIL, R. and YOUNG, D. (2011). "Post-suburbia and city-region politics". In: PHELPS, N. A. and WU, F. (eds.). International pespectives on suburbanization: A post-suburban world? Houndmills, Palgrave Macmillan.

KEIL, R.; HAMEL, P.; BOUDREAU, J.-A. and KIPFER, S. (eds.). (2016). Governing Cities Through Regions: Canadian and European Perspectives. Waterloo, Wilfrid Laurier University Press.

KENNEDY, L. (2007). Regional industrial policies driving peri-urban dynamics in Hyderabad, India. Cities, v. 24, n. 2, pp. 95-109.

KING, A. (2004). Spaces of global culture: Architecture, urbanism, identity. New York, Routledge.

KNOX, P. L. (2008). Metroburbia, USA. London, Rutgers University Press.

LANG, R. and KNOX, P. (2009). The new metropolis: Rethinking megalopolis. Regional Studies, v. 43, n. 6, pp. 789-802.

LANG, R. E. and LEFURGY, J. (2007). Boomburbs: the rise of America's accidental cities. New York, Brookings Institution Press.

LANGLEY, P. (2009). Debt, discipline, and government: Foreclosure and forbearance in the subprime mortgage crisis. Environment and Planning A, v. 41, n. 6, pp. 1404-1419.

LE GALÈS, P. (2003). Le retour des villes européennes. Sociétés urbaines, mondialisation, gouvernement et gouvernance. Paris, Presses de Sciences Po.

LEFEBVRE, H. (1968). Le droit à la ville. Paris, Anthropos.

(2003) [1970]. The urban revolution. Minneapolis, University of Minnesota Press.

LEFÈVRE, C. (1998). Gouvernements métropolitains et gouvernance dans les pays occidentaux. Politiques et Management Public, v. 16, n. 2, pp. 35-60.

LOGAN, J. and MOLOTCH, H. (1987). Urban futures: the political economy of place. Toronto, University of Toronto Press. 
MARCUSE, P. (2009). A critical approach to the subprime mortgage crisis in the United States: Rethinking the public sector in housing. City \& Community, v. 8, n. 3, pp. 351-356.

McGEE, T. (2015). "Deconstructing the Decentralized Urban Spaces of the Mega-Urban Regions in the Global South". In: KEIL, R. and HAMEL, P. (eds.). Suburban Governance A Global View. Toronto, University of Toronto Press.

McGIRR, L. (2012). The new suburban poverty. The New York Times, march 19.

McMANUS, R. and ETHINGTON, P. J. (2007). Suburbs in transition: new approaches to suburban history. Urban History, v. 34, n. 2, pp. 317-337.

MONGIN, O. (2008). Le local, l'état et la politique urbaine. Esprit, février, pp. 56-59.

MOOS, M. and MENDEZ, P. (2015). Suburban ways of living and the geography of income: how homeownership, single-family dwellings and automobile use define the metropolitan social space. Urban Studies, v. 52, n. 10, pp. 1864-1882.

NICOLAIDES, B. M. and WIESE, A. (eds.). (2006). The suburb reader. London, Routledge.

NIJMAN, J. and CLERY, T. (2015). “The United States: Suburban Imaginaries and Metropolitan Realities". In: KEIL, R. and HAMEL, P. (eds.). Suburban Governance A Global View. Toronto, University of Toronto Press.

OFFE, C. (2009). Governance: an “empty signifier". Constellations, v. 16, n. 4, pp. 550-562.

PECK, J. (2015). “Chicago-School Suburbanism”. In: KEIL, R. and HAMEL, P. (eds.). Suburban Governance A Global View. Toronto, University of Toronto Press.

PHELPS, N. and WOOD, A. (2011). The new post-suburban politics? Urban Studies, v. 48, n. 12, pp. 2591-2610.

PHELPS, N. A. and VENTO, A. T. (2015). "Suburban Governance in Western Europe". In: KEIL, R. and HAMEL, P. (eds.). Suburban Governance A Global View. Toronto, University of Toronto Press.

PHELPS, N. A. and WU, F. (eds.). (2011). International perspectives on suburbanization: A post-suburban world? Basingstoke, Palgrave Macmillan.

PHELPS, N.; WOOD, A. and VALLER, D. (2010). A post-suburban world? An outline of a research agenda. Environment and Planning A, v. 42, n. 2, pp. 366-383.

PIATTONI, S. (2010). The theory of multi-level governance: conceptual, empirical and normative challenges. Oxford, Oxford University Press.

ROY, A. (2009). The 21st-century metropolis: new geographies of theory. Regional Studies, v. 43, n. 6, pp. 819-830.

(2015). “Governing the Postcolonial Suburbs". In: KEIL, R. and HAMEL, P. (eds.). Suburban Governance A Global View. Toronto, University of Toronto Press.

SAUNDERS, D. D. (2010). Arrival city. The final migration and our next world. Toronto, Alfred A Knopf. SIEVERTS, T. (2003). Cities without cities. London, Routledge.

SOJA, E. W. (1989). Postmodern geographies. London, Verso.

(2010). Seeking spatial justice. Minneapolis and London, University of Minnesota Press. 
SWYNGEDOUW, E. (2005). Governance innovation and the citizen: The Janus face of governancebeyond-the-state. Urban Studies, v. 42, n. 11, pp. 1991-2006.

TEAFORD, J. C. (1996). Post-suburbia: Government and politics in the edge cities. Baltimore, Johns Hopkins University Press.

(2011). "Suburbia and post-suburbia: a brief history". In: PHELPS, N. A. and WU, F. (eds.). International pespectives on suburbanization: a post-suburban world? Houndmills, Palgrave Macmillan.

UNITED WAY TORONTO (2011). Vertical poverty. Poverty by postal code 2. Toronto, United Way.

VAUGHAN, L.; GRIFFITHS, G.; HAKLAY, M. and JONES, C. E. (2009). Do the suburbs exist? Discovering complexity and specificity in suburban built form.Transactions: Institute of British Geographers, n. 34, pp. $475-488$.

VIEILLARD-BARON, H. (2011). Les banlieues: des singularités françaises aux réalités mondiales. Paris, Hachette.

WU, F. and SHEN, J. (2015). "Suburban Development and Governance". In: KEIL, R. and HAMEL, P. (eds.). Suburban Governance A Global View. Toronto, University of Toronto Press.

YOUNG, D. (2006). Rebuilding the modern city after modernism. Doctoral Dissertation. Toronto, York University.

YOUNG, D. and KEIL, R. (2014). Locating the urban in-between: tracking the urban politics of infrastructure in Toronto. International Journal of Urban and Regional Research, v. 38, n. 5, pp. 1589-1608.

YOUNG, D.; WOOD, P. B. and KEIL, R. (eds.). (2011). In-between infrastructure: urban connectivity in an age of vulnerability. Praxis(e) Press.

YOUNG, R. (2015). “A Note on Governance: More Intervening Variables, Please". In: KEIL, R. \& HAMEL, P. (eds.). Suburban Governance A Global View. Toronto, University of Toronto Press.

ZHANG, J. and WU. F. (2006). China's changing economic governance: Administrative annexation and the reorganization of local governments in the Yangtze River Delta. Regional Studies, v. 40, n. 1, pp. 3-21.

Texto recebido em 12/maio/2016

Texto aprovado em 19/ago/2016 